\title{
The development of socio-communicative competence of future trainers of higher education establishments in the course of master's degree acquiring
}

\author{
Natalia Volkova ${ }^{1, *}$, Olha Lebid $^{1, * *}$, Lydia Verchenko $^{1, * * *}$, Nataliia Bidnenko ${ }^{1,2, * * * *}$, and Vira Zirka ${ }^{3, \dagger}$ \\ ${ }^{1}$ Alfred Nobel University, 18 Sicheslavska Naberezhna, Dnipro, 49000, Ukraine \\ ${ }^{2}$ Humanitas University in Sosnowiec, 43 Kilińskiego Str., 41-200 Sosnowiec, Poland \\ ${ }^{3}$ Educational Center of Foreign Languages of NAS of Ukraine, 4 Trekhsvyatitelskaya Str., Kyiv, 01601, Ukraine
}

\begin{abstract}
The article identifies one of the components of professional competence, social and communicative competence - the quality of a trainers of higher education, which is defined as complex integrative professionalpersonal formation, which determines the electiveness of interpersonal and professional interaction, allows a specialist to orient in any professional and social situation, to evaluate it adequately, to make the right decisions and achieve set goals and provides a pedagogue with personal comfort, professional electiveness and social demand in all spheres of life. The following structural components of socio-communicative competence of higher education establishment teachers are identified: motivation-valuable, cognitive, operational-active, personal, as well as a set of criteria and their indicators: motivational (presence of motivation to achieve, determination to interact, necessity in communication, self-actualization); cognitive (completeness and strength of assimilation of socio-communicative knowledge); active the level of mastery of skills (speech, nonverbal, interactive, social, information and communication); personal (social intellect, ability to empathize and reflexivity), which correlate with specified components of socio-communicative competence of higher education establishment trainers. The dissertation defined the levels of development of investigated competence (low, acceptable and high) and revealed their content. Despite the variety of solutions for its development, the higher education system needs to find new ways in this direction. The complex of education-methodological materials for HEE trainers were developed in regard to the development of the future trainers of higher education establishment in the process of Master's degree acquiring, which contains the bank of theoretical and practical lessons, educational cases, projects, exercises, trainings, role and business games; selected and adapted package of diagnostic materials for defining the level of development of socio-communicative competence of future trainers of HEE; and developed the special course program, "Socio-communicative competence of a trainer of higher education establishment". The article presents the results of an experimental study of the level of formation of social and communicative competence of trainers of higher education establishment.
\end{abstract}

\section{Introduction}

The urgency of the study is due to modern deep and rapid socio-economic, political, innovation and education transformations in the life of Ukraine, as the country focuses on integration with the civilized world community. Regarding the problems of education policy, the main tendencies are these: radical reform that acquires a new meaning; approximation to European standards; coordination of the market for educational services and the labor market; implementation of initiatives of the European Higher Education Area; and expansion of communication space which leads to a growing need for competent professionals in all spheres of human life.

Taking into account the above said, there is an urgent need to prepare future trainers of a new generation

\footnotetext{
*e-mail: npvolkova@duan.edu.ua

**e-mail: swan_ov@ukr.net

***e-mail: lydiaverchenko@gmail.com

****e-mail: bidnenko.n@duan.edu.ua

†e-mail: verazirka@ukr.net
}

of higher education, in order to meet modern requirements of employers, to be competent in social interaction with both individuals and social institutions, to realize their own needs and goals by building partnerships with others, matching their expectations, needs, effectively interacting with the internal professional-communicative environment and the external social environment of society as a result of the presence of socio-communicative knowledge and skills, which are professionally important communicative qualities. These factors are a large part of the social order for the system of professional pedagogical education, which has a clearly defined legal framework: the National Doctrine of Education in Ukraine in the 21st century [1], the National Strategy for Education in Ukraine until the year 2021 [2], the Law of Ukraine "On Higher Education" [3], which provide measures for a trainer of higher education establishment (hereinafter - HEE) to become a guarantee of high quality education, which would change the meaning and nature of social, professional communication in accordance with the requirements of the renewed higher education establishment. 
Various aspects of the problem of sociocommunicative competence have attracted attention of many researchers. Scientists studied the structure and content of socio-communicative competence (L. Anfalova [4], B. Burleson [5], S. Vdovina [6], J. Greene [5], O. Kovaleva [7], N. Levus [8], L. Newell [9], S. Olsen [9], V. Pomiluyko [10], O. Popova [11], O. Timofeeva [12], T. Tomenko [13], J. Fruktova [14], C. Hart [9], A. Tsvetkova [6], O. Shumilova [15], etc.), the peculiarities of social competence (G. Gedviliene [16], S. Gerviene [16], H. Han [17], K. Kemple [17], A. Pasvenskiene [16], S. Ziziene [16], T. Tulpa [18], etc.), especially, the competence of trainers of higher education (D. Gubareva [19], M. Matishak [20], etc.) and communicative competence (S. Saleh [21], L. Tarvin [22], N. Yurijchuk [23], etc.).

The issue of professional teaching of future trainers of higher education establishments in the course of Master's degree acquiring is studied by researchers in the following different areas: organization of Master's degree acquiring of future trainers of higher education establishment to form their potential for professional self-development (R. Tsokur [24]); pedagogical training of Master's degree students on conditions of degree education (S. Vitvytska [25]); training higher education professionals for teaching in the Internet and after Covid-19 crisis (C. Rapanta, L. Botturi, P. Goodyear, L. Guàrdia \& M. Koole [26]); development of the system of trainers' teaching in higher education establishment (Y. Sorokopud [27]); teaching of future trainers of higher education establishment for pedagogical activity (O. Momot [28], K. Vlasenko [29]); theoretical substantiation and experimental verification of organization and pedagogical conditions to create pedagogical culture of the future trainers of higher education establishment (S. Chorna [30]); formation of professionalism of future trainers of higher education establishment in pedagogy in the process of professional training (I. Mazur [31]), the development of relational competencies of the future trainers of higher education establishment (N. Dută, E. Rafaila [32]) and others.

With this in mind, the aim of the article is to reveal the essence, structure and indicators of development of sociocommunicative competence of future trainers of higher education establishment, and to develop, substantiate and experimentally test the technology of development of sociocommunicative competence of future trainers in higher education institutions.

\section{Research methods}

To achieve the goal of the article, a set of qualitative and quantitative research methods is given: theoretical - analysis, summarizing and systematization of scientific statements for developing theoretical foundations of the development of socio-communicative competence of future trainers of higher education establishment in the process of Master's degree acquiring; empirical: the method of "Assessment of the need to achieve", the method of "Determining the orientation of the individual" (B. Bass), method "The Necessity for communication" (Y. Orlov), evaluation scale method "Self-actualization test" (Y. Alyoshin,
L. Gozman), surveys, analytical maps to level the development of socio-communicative skills, method of determining the level, method of reflectivity (A. Karpov, V. Ponomareva), methods of diagnosis of social intelligence (N. Hall), methods of diagnosis of the level of empathy (V. Boyko); pedagogical experiments (ascertaining, formative, control) in order to determine the effectiveness of the implementation of technology for the development of socio-communicative competence of future trainers of higher education establishments in the course of Master's degree acquiring, methods of mathematical statistics to determine the statistical significance of the results obtained during experimental work.

\section{Results and discussion}

The socio-communicative competence of a future trainer of higher education establishments is considered to be stable, complete and integral to personal development, which allows a pedagogue to effectively interact with an internal professional-communicative environment and an external social environment of a society to perform socio-communicative activity by acquiring socio-communicative knowledge and skills (such as speech, non-verbal, interactive, social and informationcommunicational), important professional communicative qualities (such as intellect, empathy and reflexivity).

The presence of socio-communicative competence for a trainer of higher education establishment and other competences, such as complex integrative professionalpersonal formation, which determines the effectiveness of interpersonal and professional interaction, allows a specialist to orient in any professional and social situation, to evaluate it adequately, to make the right decisions and achieve set goals and provides a pedagogue with personal comfort, professional effectiveness and social demand in all spheres of life.

This phenomenon is cross-curricular (formed and operates in several related fields and has an interdisciplinary nature, which enables solving meta-tasks) and it is multifunctional, as mastering this competence allows the graduate to solve various problems in professional, social and personal life.

Under the development of socio-communicative competence of future trainers of higher education establishments in the course of Master's degree acquiring we understand the purposeful process of systematic accumulation in its content of positive quantitative and qualitative changes that allow us to interact effectively with the internal professional and communicative environment and the external social environment of society, to carry out social and communicative activities, notably the establishment and development of interpersonal contacts between a trainer and social subjects (students, colleagues, professionals, employers, etc.), which also includes an information exchange, modeling a common strategy of interaction and achieving the goal through the management of social communication processes.

Based on the analysis of works of S. Vdovina, A. Tsvetkova [6], O. Kovaleva [7], O. Pryamikova [33], 


\section{SOCIO-COMMUNICATIVE COMPETENCE OF FUTURE HIGHER EDUCATION ESTABLISHMENT TEACHER}

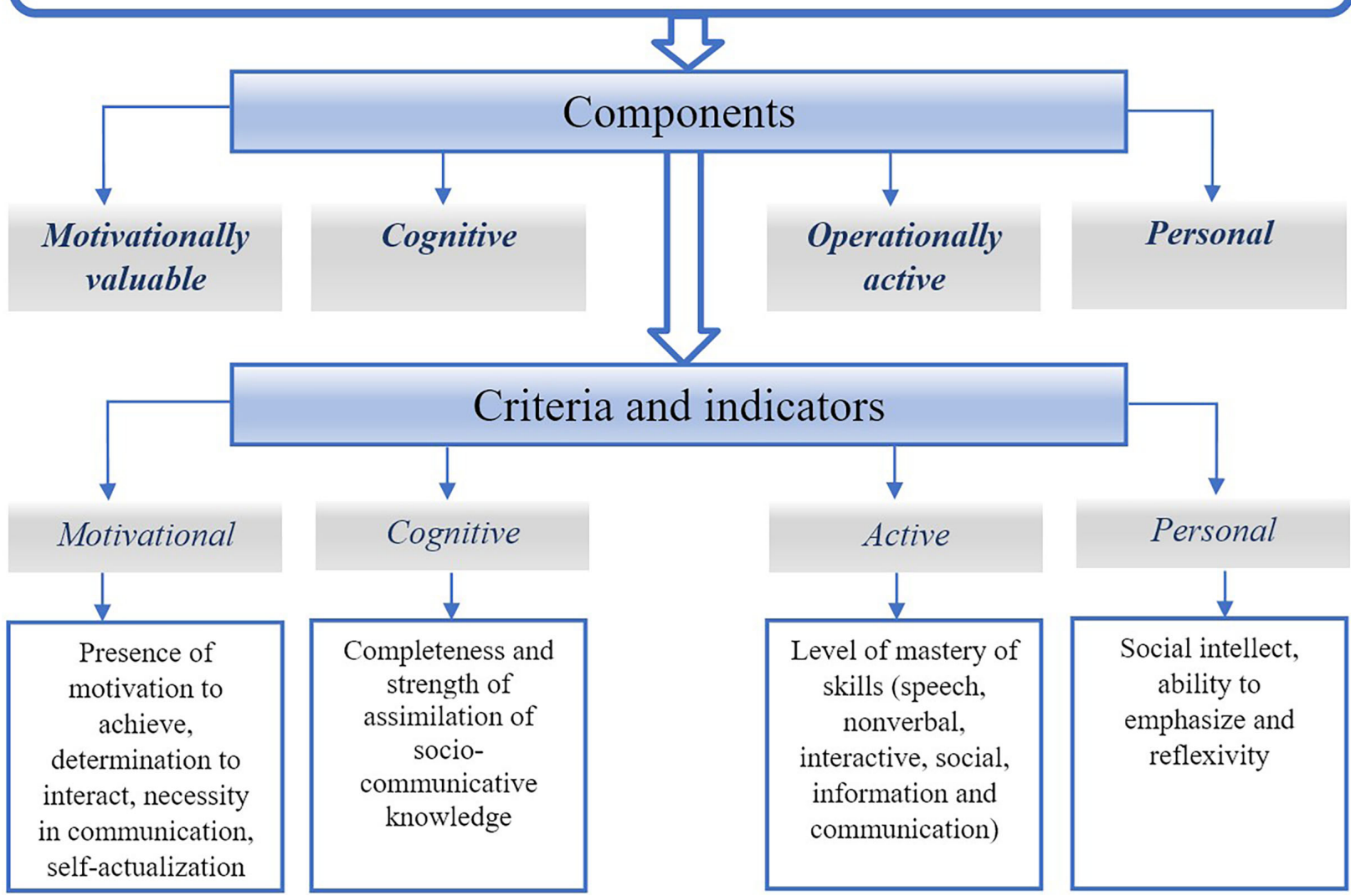

Figure 1. The structure of socio-communicative competence of future trainers of higher education establishments in the course of Master's degree acquiring

T. Tomenko [13], the following structural components of socio-communicative competence of higher education establishment teachers are identified: motivation-valuable, cognitive, operational-active, personal, as well as a set of criteria and their indicators: motivational (presence of motivation to achieve, determination to interact, necessity in communication, self-actualization); cognitive (completeness and strength of assimilation of socio-communicative knowledge); active the level of mastery of skills (speech, nonverbal, interactive, social, information and communication); personal (social intellect, ability to empathize and reflexivity), which correlate with specified components of socio-communicative competence of higher education establishment trainers. The dissertation defined the levels of development of investigated competence (low, acceptable and high) and revealed their content.

In order to develop the socio-communicative competence of Master's degree students, we formulated theoretical techniques of development of socio-communicative competence of future trainers of higher education establishments in the course of Master's degree acquiring, which contains the following steps: conceptual, motivational-stimulation, content-processional, practical and diagnostic-correctional.
The conceptual stage covers finding the aim of technique, particularly the development of sociocommunicative competence of future trainers of higher education establishments in the course of Master's degree acquiring and encircling the following tasks: stimulation and professional motivation of Master's degree students, mastering socio-communicative knowledge by Master's degree students, honing socio-communicative skills (speech, non-verbal, communicative, interactive, social and information-communicative) required for performing socio-communicative activity; enriching personal experience of Master's degree students in productive socio-communicative activity, formulating a personal-value attitude for self-improvement of sociocommunicative competence; formulating methodological approaches (systematic, active, competent, andragogical, contextual, personally oriented, participative, synergetic); defining principles of studies (subjective, communicative collaboration and dialogue, increasing the number of social development mechanisms, worldview pluralism, differentiation, self-improvement and mutual improvement, competent "upgrading" and professional mobility); carrying out preliminary diagnostics of a development level of Master's degree students' socio-communicative 
competence and defining an educational and methodical seminar-practicum for professors which prepare the future teachers of HEE according to the program 011 Educational, Pedagogical sciences.

The motivation-stimulating stage of the technique orients towards the following: formation on the part of Master's degree students of a personal understanding of socio-communicative activity; self-improvement of personal confidence level, values and goals of communication; deep emotional attitude towards the world, people and themselves.

The essence of contextual-procedural stage of techniques, which is aimed at the content transformation of the education process in the direction of mastering sociocommunicative knowledge and skills of Master's degree students. The foundation of this stage is based on a renewed list of disciplines: "Psychology of higher institution", "Modern techniques of organization of higher establishment educational process", "Professional pedagogical communication", "Crises and deformations of a trainer's professional development of higher education establishment"; implementation of the following methods of teaching: dialogue-discussion (dispute, debates, discussion, brainstorming, round-table, symposium); situational (problematic situations, case method, communicative situational tasks). The key role is allocated to strategies ("Reciprocal teaching" by Brown and Palinscar, "Zigzag", "Reverse zigzag" by T. Hedeen), "Round table writing", "Think in pairs") and techniques ("aquarium", "hot chair", "puzzle", "puzzle-2", "team education", brainstorming, "Delbeck method", "synaptic method", "mind mapping", collaborative education and coaching methods.

Implementation of professionally oriented activities involving Master's degree students in active communication and interaction allows them first unconsciously and then consciously to develop ideas about the norms, values of professional teaching, including social communication activities, behaviors and their own participation in it. This adds a communicative, active, interactive character to the process of professional teaching of higher education establishment trainers.

It provides a harmonic combination of lecture (interactive lecture, lecture-discussion, briefing lecture, problembased lecture), seminars (Socratic seminar, intervision seminar, seminar for defending projects and individual artistic tasks) and practice-based lessons (training).

Emphasis is placed on coaching methods: the method of specific situations (improvement of knowledge is possible only through a comprehensive consideration, study and discussion of specific pedagogical situations); method of emotional stimulation of learning (based on the principle of formation and increase of cognitive interest of Master's degree students through the creation of positive emotions to the work of a trainer, motivation for the educational process and positive motivation for pedagogical activity of future trainer of HEE). The method of creating a situation of cognitive discussion (activation of learning through the statement "truth is born in discussion", and the search for truth is always of interest); "mosaic" method (the method of dividing responsibilities in a group of Master's degree students based on their independence in the process of distribution their responsibility for it).

The most important role is assigned to the developed author's special course "Socio-communicative competence of a higher education establishment trainer". This course aims to provide general theoretical preparation of the future trainers of HEE in the field of professional socio-communicative activity and development of components of their social and communicative competence.

The program of the special course is designed for three credits (90 hours): lectures - 10 hours, seminars - 12 hours, practical classes -14 hours, individual work -8 hours, independent work -46 hours.

The content of the special course includes two main modules: "Socio-communicative competence as a basis of professional competence of a higher education institution trainer" and "Socio-communicative competence of a higher education institution trainer: methods, means and technologies of formation".

The special course program provides a harmonic combination of lectures (interactive lecture, lecture-discussion, briefing lecture, problem-based lecture), seminars (interactive seminar, intervision seminar, Socratic seminar, seminar for defending projects and individual artistic tasks) and practice-based lessons using interactive methods of teaching: dialogue-discussion (dispute, debates, discussion, 'brainstorming', round-table, case-method ('Help and do not cause inconvenience', 'Look at the ceiling', 'Brilliant cartoonist', 'Fire on the host'); games (business, roleplay 'Negotiation', 'Business conversation'), sociopsychological games 'Gelactions', 'Shipwreck'); training 'Effective interaction as a means of conflict prevention'). Considerable attention is paid to the exercises ('Being a trainer is (means)...' 'Understanding the image who I am', 'Carousel', 'Self-presentation', 'What are we like?', 'Influence of emotional states on relationships', 'Prohibition to say 'no', 'Collection of phrases for contact', 'Constructive style of behavior in conflict', etc.). In the course of training, tutoring of Master's degree students should be organized and compulsory.

During the development of socio-communicative competence of the future trainers of HEE the attention is focused on the need for active participation of Master's degree students in various forms of extracurricular activities, the main purpose of which is to set up conditions for creative intellectual development of graduate students in their free time; preparation of graduate students for interaction in the social and professional environment; introduction of innovative forms and methods of organization such a training. It is proved that extracurricular work should be professionally oriented to allow Master's degree students to gain initial practical experience, to form skills of independent action, to find their own professional style of interaction. In the study, the preference was given to training that helped graduate students to learn, to get the opportunity to feel like a full-fledged trainer, to be more interested in professional growth and be confident that they can grow professionally under the condition of successful activities.

The practical stage involves Master's degree students in the practical socio-communicative activities of a trainer, 
analytical and evaluative, exploratory and practical activities that all ensure the formation of a reflexive position in graduates; participation in the competition "The best future trainer of higher education establishment", the implementation of practical teaching activities; involvement in master classes; compiling a portfolio.

The practical stage is implemented during the assistant practice ( 3 credits), which is an important component of the educational process and aims at teaching graduates to creatively apply their new teaching theoretical knowledge and practical skills acquired in the study of psychological, pedagogical and special disciplines, to promote the development of future trainers of higher education institutions to have a steady interest in pedagogical activity. The specificity of the practical activity of graduate students is more identified with the pedagogical activities of HEE trainer, meanwhile the practice is carried out in conditions adequate to the conditions of future independent pedagogical activity. It is important that the activity of the Master's degree students during the internship is characterized by the same variety of functions as the work of a trainer.

During the internship, graduate students must take part in a master-class session. Their implementation provides practical skills in the application of various methods, techniques and technologies of teaching in order to increase the level of pedagogical skills, exchange of pedagogical experience, involvement in new areas of knowledge, expanding worldview $[34,35]$.

The diagnosis-resultative stage provides control, selfanalysis, correction of imperfections in the process of development of the researched competence; diagnostics of the final level of development of socio-communicative competence of future trainers of higher education institutions. Diagnosis becomes a means of including graduate students in correctional work on themselves, their own qualities, behavior and self-diagnosis, which allows them to identify behavioral and personal complexes, more constructively formulate their own problems, the essence of their impact on interaction in the pedagogical process.

The experimental study was conducted in the following stages: ascertaining, forming and controlling.

The ascertaining stage of the experimental work was aimed at: studying and analyzing the state of the research problem; formulation of goals and objectives; establishment of the quantitative and qualitative composition of the participants of the experiment (scientific and pedagogical workers, curators of academic groups, Master's degree students of the specialty 011 Educational, pedagogical sciences); primary diagnostics in order to obtain initial data on the level of development of social and communicative competence of Master's degree students.

The forming stage of the experiment involved the implementation of experimental testing of the hypothesis, the practical implementation of the developed and theoretically grounded technology for the development of social and communicative competence of future trainers of higher education institutions in the process of Master's training. Empirical data were collected at Alfred Nobel University, Donbas State Pedagogical University, Classical Private University (Zaporizhzhya), Mykhailo Os- trogradsky National University of Kremenchug (during 2017-2020), 17 professors of the universities mentioned above and 194 Master's degree students who are obtaining second level (Master's degree) in the educationalprofessional program Pedagogy of higher education establishment in specialty 011 Educational, pedagogical sciences participated in the experiment. They were divided into two groups: experimental - 98 people; controlling - 96 people (worked on the traditional curriculum), as well as 17 higher education trainers of these institutions of higher education.

The controlling stage of the experiment included: monitoring the results of the experimental study; description of the course and results of the study; mathematical and statistical data processing; expert evaluations; registration of results of scientific search, definition of prospects of the further researches.

The results on the dynamics of changes in indicators of the levels of development of the components of sociocommunicative competence of Master's degree students of the control and experimental groups are given in table 1.

Comparison of data on the level of development of the components of social-communicative competence of Master's degree students of the experimental and control groups shows significant positive changes at all levels that occurred during the formative stage of the experiment.

Analyzing the data on the levels of development of the motivationally valuable criterion of socio-communicative competence of graduate students (see table 1), it should be noted that in two years in the control group there were some changes. However, the dynamics was insignificant $(+2.0 \%)$. Some positive changes were found in graduate students who had a low level of development of motivationally valuable criteria of socio-communicative competence (from 40,7 to $34,4 \%$ ). These results regarding minor changes in the control group indicate a lack of purposeful work on the development of socio-communicative competence of Master's degree students. According to the results fixed in the experimental group, we can say that after the formative stage of the experiment in the level of development of the motivationally valuable criterion of sociocommunicative competence there are significant positive changes. Indicators of the motivationally valuable criterion were: for high level Master's degree students $+18,4 \%$, acceptable level $+8,1 \%$, low level $+26,5 \%$. We believe in the effectiveness of our chosen methods and techniques of motivation and stimulating the educational activities of graduate students, which included the inclusion of emotionally rich and professionally oriented material, meetings and round tables with leading scientific and pedagogical staff of HEE. Exercises and methods of coaching were developed and tested, the implementation of which ensured the growth of students' cognitive interest in the work of a future trainer of higher education establishments and positive motivation for future pedagogical activity.

Regarding the dynamics of the levels of development of cognitive criterion of socio-communicative competence of Master's degree students, the results obtained indicate rapid positive changes. Thus, after the formation phase of the experiment in the experimental group, the number 
Table 1. Dynamics of levels' indicators of socio-communicative competence development of Master's degree students in control and experimental groups

\begin{tabular}{|c|c|c|c|c|}
\hline \multirow{4}{*}{ Level } & \multicolumn{4}{|c|}{ Group } \\
\hline & \multirow{2}{*}{\multicolumn{2}{|c|}{ Control group (96 students) }} & \multicolumn{2}{|c|}{ Experimental group (98 students) } \\
\hline & & & \multicolumn{2}{|c|}{ Experiment stage } \\
\hline & Statement & Control & Statement & Control \\
\hline \multicolumn{5}{|c|}{ Criterion of socio-communicative competence } \\
\hline \multicolumn{5}{|c|}{ Motivationally valuable } \\
\hline High & 20,8 & 22,9 & 20,4 & 38,8 \\
\hline Acceptable & 38,5 & 42,7 & 42,9 & 51,0 \\
\hline Low & 40,7 & 34,4 & 36,7 & 10,2 \\
\hline \multicolumn{5}{|c|}{ Cognitive } \\
\hline High & 25,0 & 25,9 & 22,4 & 38,8 \\
\hline Acceptable & 29,2 & 33,4 & 29,6 & 46,9 \\
\hline Low & 45,8 & 40,7 & 48,0 & 14,3 \\
\hline \multicolumn{5}{|c|}{ Operationally active } \\
\hline High & 21,9 & 22,9 & 19,4 & 39,8 \\
\hline Acceptable & 35,4 & 38,5 & 38,8 & 46,9 \\
\hline Low & 42,7 & 38,6 & 41,8 & 13,3 \\
\hline \multicolumn{5}{|c|}{ Personal } \\
\hline High & 21,9 & 22,9 & 19,4 & 36,7 \\
\hline Acceptable & 31,3 & 33,4 & 33,7 & 52,1 \\
\hline Low & 46,8 & 43,7 & 46,9 & 11,2 \\
\hline
\end{tabular}

of graduate students has rapidly increased, whose performance is now identified at the high level criterion (from $22,4 \%$ to $38,8 \%$ ). It is increased by $16,4 \%$. Qualitative analysis of the results showed that these Master's degree students have stable views on the socio-communicative activities of the future trainers of HEE, which requires a constant self-improvement. They have obtained strong, deep and effective knowledge of the following: the essence of socio-communicative competence of a trainer, their personal structure; social interaction strategies and communication strategies; methods of conflict prevention and regulation in the educational environment; methods and means of formation of socio-communicative competence of the trainers and their implementation of direct and indirect socio-communicative activity. We have to state that the number of low-level criterion among Master's degree students decreased significantly (from $48,0 \%$ to $14,3 \%$ ). It is increased by $33,7 \%$.

Regarding the data of the control group, it can be asserted that there have been some changes, but not significant: high level Master's degree students changed from $25,0 \%$ to $25,9 \%$, acceptable - from $29,2 \%$ to $33,4 \%$, low from $45,8 \%$ to $40,7 \%$. The detected increase was: $+0,9 \%$; $+4,2 \% ;-5,1 \%$. These results indicate that an effective technology that was aimed at the development of sociocommunicative competence of the future trainers of HEE in the process of Master's degree acquiring was properly chosen.

Significant changes have taken place in the level of development of the operationally active criterion. Diagnosis showed that in the control group, if the number of Master's degree students with a high level is $22,9 \%$ (compared to $21,9 \%$ ), then in the experimental $-39,8 \%$ (compared to $19,4 \%)$. It is increased accordingly $(+1 \%$ and
$+20,4 \%$ ). Indicators of the low level of development of the operationally active criterion among Master's degree students have dropped significantly. In the experimental group, there was an increase by $28,5 \%(-4,1 \%$ in the control group). The changes occurred at an acceptable level: in the experimental group $(+20,4 \%)$, and in the control group $(+3,1 \%)$. We believe that it was expedient to introduce the educational process of the author's special course "Socio-communicative competence of a trainer of higher education establishment", interactive seminars, discussion seminars, Socratic seminar, seminars-defense of projects, seminars 'Debriefing', 'Professor versus Master's degree student', seminar 'Dispute in the rows', practical classes with the use of exercises, interactive teaching methods: dialogue-discussion, game, training, situational (case method); strategies and tactics of collaborative learning; types of group, in pairs, individual work; various forms of extracurricular activities.

Furthermore, we have to admit that the indicators of the personal criterion have also changed significantly. In the experimental group, noticeable positive changes occurred at all levels: high level Master's degree students - from $19,4 \%$ to $36,7 \%$ (increased by $17,3 \%$ ); acceptable level - from $33,7 \%$ to $52,1 \%$ (increased by $18,4 \%$ ); low level - from $46,9 \%$ to $11,2 \%$ (decreased by $35,7 \%$ ). In the control (regular) group, the changes were insignificant: high level Master's degree students - from 21,9\% to 22,9\% (increased by $+1,0 \%$ ); acceptable level - from $31,3 \%$ to $33,4 \%$ (increased by $+2,41 \%$ ); low level - from $46,8 \%$ to $43,7 \%$ (decreased by $3,1 \%$ ).

Substantiation of the conclusions and verification of statistical differences of Master's degree students of control and experimental groups were carried out using Pearson's chi-squared distribution test $\left(\chi^{2}\right)$. 
Table 2. The results of calculation of $\chi_{\text {exp }}^{2}$ and $\chi_{\text {ctrl }}^{2}$ for the criteria of socio-communicative competence of Master's degree students in Experimental group (EG) and Control group (CG) at statement and control stage of the experiment

\begin{tabular}{|c|c|c|c|c|}
\hline \multirow{3}{*}{ Criterion } & \multicolumn{4}{|c|}{ Experiment stage } \\
\hline & \multicolumn{2}{|c|}{ Statement } & \multicolumn{2}{|c|}{ Control } \\
\hline & $\chi_{\text {exp }}^{2}$ & $\chi_{c t r l}^{2}$ & $\chi_{\text {exp }}^{2}$ & $\chi_{\text {ctrl }}^{2}$ \\
\hline Motivationally valuable & 0,48 & \multirow{4}{*}{5,99} & 16,25 & \multirow{4}{*}{5,99} \\
\hline Cognitive & 0,29 & & 15,73 & \\
\hline Operationally active & 0,25 & & 16,10 & \\
\hline Personal & 0,18 & & 23,92 & \\
\hline
\end{tabular}

Table 3. Dynamics of indicators of levels of the development of socio-communicative competence of Master's degree students in Control group (CG) and Experimental group (EG)

\begin{tabular}{|c|c|c|c|c|}
\hline \multirow{4}{*}{ Level } & \multicolumn{4}{|c|}{ Group } \\
\hline & \multicolumn{2}{|c|}{ CG (96 students) } & \multicolumn{2}{|c|}{ EG (98 students) } \\
\hline & \multicolumn{4}{|c|}{ Experiment stage } \\
\hline & Statement & Control & Statement & Control \\
\hline High & 18,8 & 22,9 & 19,4 & 39,8 \\
\hline Acceptable & 31,2 & 32,3 & 33,7 & 49,0 \\
\hline Low & 50,0 & 44,8 & 46,9 & 11,2 \\
\hline
\end{tabular}

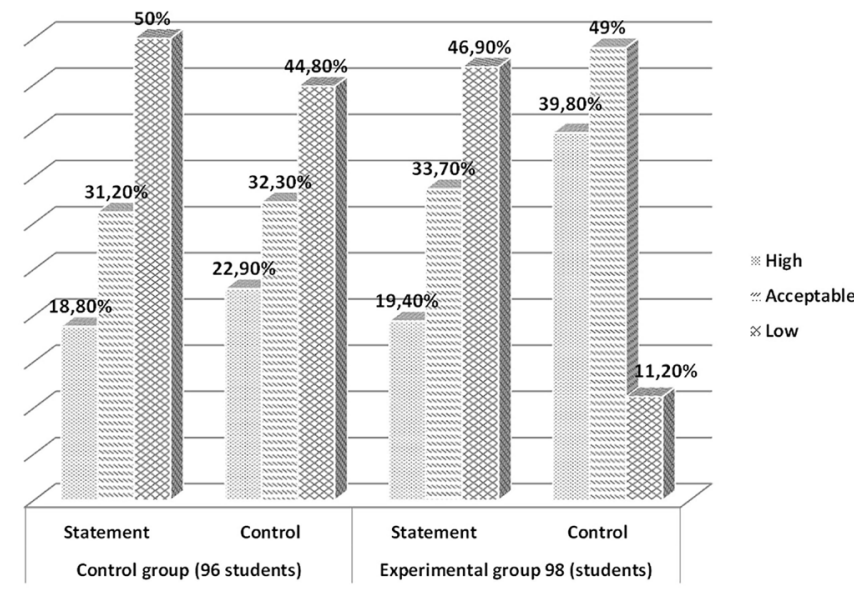

Figure 2. Dynamics of indicators of levels of the development of socio-communicative competence of Master's degree students (\%)

At the end of the formative stage of the experiment, a conducted study was aimed at determining the dynamics of levels of the development of socio-communicative competence of Master's degree students in the studied groups (table 3, figure 2).

Comparing the results obtained at the control stage of the experiment, we have to state that after the formative stage of the study in the experimental group we see a rapid increase in the number of graduate students, who correlate with a high level: the percentage of Master's degree students in the experimental group with high level performance is increased from $19,4 \%$ to $39,8 \%$. The number of the future trainers of HEE (Master's degree students), who showed a low level performance in the beginning of the experiment, is decreased significantly at the end of it (from $46,9 \%$ to $11,2 \%$ ). In the control (or regular) group there were positive, but insignificant changes: high level of Master's degree students is changed - from 18,8\% to $22,9 \%$, acceptable level - from $31,2 \%$ to $32,3 \%$, low level - from $50,0 \%$ to $44,8 \%$.

In the experimental group, the difference, before and after the experiment, was found to be statistically significant $\left(\chi_{\text {emp }}^{2}=375.35>\chi_{\text {critical }}^{2}=5.99\right)$, in comparison to the control group, where the difference was statistically insignificant $\left(\chi_{e m p}^{2}=3.36<\chi_{\text {critical }}^{2}=5.9\right.$ The obtained results allow us to conclude that there is a significant difference between the results of the control and experimental groups (with a probability of $95 \%$ ).

Qualitative analysis of the results obtained in the study shows that the implementation of the technology for the development of socio-communicative competence of the future trainers of HEE in the process of Master's degree acquiring has led to significant positive changes in the phenomenon of the educational process. This allows us to state that the process of development of sociocommunicative competence of the future trainers of higher education establishments has taken place, and the declared goal of the study has been successfully achieved.

\section{Conclusions and prospects for further research}

The introduction of technology for future trainers of higher education establishments in the process of Master's degree acquiring, based on the study of scientific research of foreign and domestic scientists on the problem raised in the study, the improved content, methods (dialoguediscussion, game, training, situational learning) and forms of education (lectures, practical and seminar classes, extracurricular activities, practice), aimed at the development of motivational-value, cognitive, operationalactivity, personal components of social and communicative competence of future trainers of higher education establishments in the process of Master's degree acquiring are substantiated in the article.

The topicality of the study due to the modernization of socio-economic, political, innovation and educational spheres of Ukrainian society, which requires the introduction of new approaches to shaping the personality of future trainer of higher education, who must be ready for social interaction is revealed.

The analysis of the scientific source base gave grounds to clarify the essence of the key concept of the study: "social and communicative competence of future trainers of higher education establishment". We interpret this competence as a stable, holistic, integrative formation of personality, which allows the trainers to interact effectively with the internal professional and communicative environment and the external environment of society, to carry out social and communicative activities through the acquisition of social and communicative knowledge and speech, nonverbal, interactive, social, informative and communicative skills, professionally important communicative qualities (social intelligence, ability to empathy, reflexivity). 
The experimental method confirms the importance of focusing on the four components of social and communicative competence of future trainers of higher education establishments.

The following structural components of the studied competence are substantiated: motivational-value, cognitive, operational-activity, personal components, as well as a set of criteria and their indicators, motivational component (presence of achievement motivation, focus on interaction, communication needs, self-actualization); cognitive component (completeness and strength of assimilation of social and communicative knowledge); activity component (level of mastering speech, nonverbal, interactive, social, information and communication skills); personal component (social intelligence, ability to empathy, reflexivity).

The effectiveness of the development technology of social and communicative competence of future trainers of higher education establishments in the process of Master's degree acquiring is theoretically substantiated. It is proved that the acquiring process contains the following stages: conceptual, motivational-stimulating, content-procedural, practical, diagnostic-corrective.

According to the results of the controlling stage of the study in EG compared to CG where the educational process introduced the technology of social and communicative competence of future trainers of higher education establishments in the process of Master's degree acquiring has revealed the significant positive changes in the levels of social and communicative competence of Master's degree students: the percentage of Master's degree students in the experimental group with the high level performance is increased from $19,4 \%$ to $39,8 \%$, the number of future trainers of HEE (Master's degree students), who showed a low level performance is decreased significantly (from $46,9 \%$ to $11,2 \%$ ), in the control (or regular) group there are positive, but insignificant changes: high level of Master's degree students is from $18,8 \%$ to $22,9 \%$, acceptable level - from $31,2 \%$ to $32,3 \%$, low level - from $50,0 \%$ to $44,8 \%$. Substantiation of the conclusions and verification of statistical differences of Master's degree students of control and experimental groups were carried out using Pearson's chi-squared distribution test $\left(\chi^{2}\right)$.

The assumption of the authors of the article, that the success of the development of social and communicative competence of future trainers of higher education establishments in the process of Master's degree acquiring provided with the introducing the theoretically substantiated development technology of social and communicative competence of future trainers of higher education establishments in the process of Master's degree acquiring aimed at the development of motivational-value, cognitive, operational-activity, personal components of defined competence, is confirmed.

The prospects of further research is recognized in the analysis of professional self-realization paths of the Master's degree graduates in education-professional programs in higher education establishments of Ukraine.

\section{References}

[1] Natsionalna doktryna rozvytku osvity Ukrainy (National doctrine of education development of Ukraine) (2002), http://zakon2.rada.gov.ua/ laws/show/347/2002

[2] Natsionalna stratehiia rozvytku osvity $v$ Ukrainy na period do 2021 roku (National strategy for the development of education in Ukraine until 2021) (2013), http://www.president.gov.ua/ documents/15828.html

[3] Law of Ukraine On Higher Education (2014), https://zakon.rada.gov.ua/laws/show/ 1556- 18

[4] L. Anfalova, E. Kalugina, Scientific Review. Pedagogical Sciences p. 50-51 (2015)

[5] J. Greene, B. Burleson, Handbook of Communication and Social Interaction Skill (Lawrence Erlbaum Associates, 2003)

[6] S. Vdovina, A. Tsvetkova, The concept pp. 1-6 (2013)

[7] O. Kovalova, Psykholohichni osoblyvosti rozvytku sotsialno-komunikatyvnoi kompetentnosti vchyteliv (Psychological features of the development of social and communicative competence of teachers) (2018)

[8] N. Levus, Scientific studies in social and political psychology p. 180-189 (2011)

[9] C. Hart, L. Newell, S. Olsen, Parenting skills and social-communicative competence in childhood (2003), https://scholarsarchive.byu. edu/facpub/4133

[10] V. Pomyluiko, Psycholinguistics p. 175-186 (2017)

[11] E. Popova, I. Belonovskaia, Teoria $i$ praktika razvitiia sotsialno-kommunikativnoi kompetentnosti sotrudnikov politsii v usloviiakh srednego professionalnogo obrazovaniia (Theory and practice of the development of social and communicative competence of police officers in the context of secondary vocational education) (Universitet, Orenburg, 2015)

[12] O. Tymofieieva, Zbirnyk naukovykh prats . Pedahohichni nauky pp. 152-157 (2016)

[13] T. Tomenko, Formirovanie sotsialnokommunikativnoi kompetentnosti v professionalnoi podhotovke studentov meditsinskoho kolledzha (Formation of social and communicative competence in the professional training of medical college students) (2006)

[14] Y. Fruktova, Pedagogical process: theory and practice p. 184-194 (2013)

[15] E. Shumilova, Formirovanie sotsialnokomunikativnoi kompetentnosta budushchikh pedagogov professionalnogo obucheniia $v$ sisteme vysshego obrazovaniia (Formation of social and communicative competence of future teachers of vocational training in the higher education system) (2011)

[16] G. Gedviliene, S. Gerviene, A. Pasvenskiene, S. Ziziene, European Scientific Journal (2014) 
[17] H. Han, K. Kemple, Early Childhood Education Journal 34, 241-246 (2006)

[18] T. Tiulpa, Young scientist p. 142-145 (2020)

[19] D. Hubarieva, Bulletin of Alfred Nobel University. Pedagogy and psychology. Pedagogical sciences p. 27-32 (2020)

[20] M. Matishak, Educational space of Ukraine p. 110-115 (2015)

[21] S. Saleh, University Bulletin pp. 101-110 (2013)

[22] L. Tarvin, Communicative competence: Its definition, connection to teaching, and relationship with interactional competence (2014), 10.13140/RG. 2 . 1.3214 .2807

[23] N. Yuriichuk, Bulletin of the Taras Shevchenko National University 'Chernihiv Collegium' pp. 224-228 (2019)

[24] R. Tsokur, Formuvannia potentsialu profesiinoho samorozvytku $v$ maibutnikh vykladachiv vyshchoi shkoly u protsesi mahisterskoi pidhotovky (Formation of potential of professional self-development at future teachers of higher school in the course of master's preparation) (2004)

[25] S. Vitvytska, Teoretychni i metodychni zasady pedahohichnoi pidhotovky mahistriv $v$ umovakh stupenevoi osvity (Theoretical and methodical bases of pedagogical preparation of masters in the conditions of degree education)

[26] C. Rapanta, L. Botturi, P. Goodyear, L. Guàrdia, M. Koole, Postdigital Science and Education 2, 923-945 (2020)

[27] Y. Sorokopud, Razvitie sistemy podgotovki prepodavatelei vysshei shkoly (Development of the system of training teachers of higher education) (2012)
[28] O. Momot, Pidhotovka maibutnikh vykladachiv vyshchykh navchalnykh zakladiv do pedahohichnoi diialnosti $v$ umovakh mahistratury (Preparation of future teachers of higher educational institutions for pedagogical activity in the conditions of a magistracy) (2016)

[29] K. Vlasenko, O. Chumak, I. Sitak, I. Lovianova, O. Kondratyeva, Universal Journal of Educational Research 7, 1892 (2019)

[30] S. Chorna, Formuvannia pedahohichnoi kultury maibutnoho vykladacha vyshchoi shkoly v umovakh mahistratury (Formation of pedagogical culture of the future teacher of higher school in the conditions of a magistracy) (2008)

[31] N. Mazur, Formuvannia profesionalizmu maibutnoho vykladacha pedahohiky u protsesi profesiinoi pidhotovky (Formation of professionalism of the future teacher of pedagogy in the process of professional training) (2010)

[32] N. Dută, T. Rafaila, Procedia - Social and Behavioral Sciences 128, 522-526 (2014)

[33] E. Priamikova, Sociological research p. 126-132 (2009)

[34] N. Volkova, Interaktyvni tekhnolohii navchannia $u$ vyschii shkoli (Interactive learning technologies in high school) (Alfred Nobel University, Dnipro, 2018)

[35] V.F. Zhyvodor, I.I. Havrylenko, T.V. Hrebenyk, S.S. Dieniezhnikov, O.A. Zabolotna, Teoretychni ta metodychni zasady mahisterskoi pidhotovky vykladacha vyshchoi shkoly (Theoretical and methodical bases of master's preparation of the teacher of higher school) (Sumy State Pedagogical University named after A.S. Makarenko, Sumy, 2014) 